Section Editor

Robert C. Griggs, MD
Editors' Note: Dr. Egan inquires about the possibility of Tournay phenomenon in Kawasaki and Mayer's "Tadpole pupil." Dr. Charles, in reference to "Disease-modifying drugs for multiple sclerosis in pregnancy: A systematic review," suggests that it might be appropriate to continue glatiramer acetate in women trying to conceive given the lack of evidence of fetal risk. Authors Tremlett et al. advise that, at this point, each case should continue to be assessed individually. Megan Alcauskas, MD, and Robert C. Griggs, MD

\section{TADPOLE PUPIL}

Robert A. Egan, Napa, CA: Drs. Kawasaki and Mayer ${ }^{1}$ present a nice example of a teardrop-shaped or tadpole pupil in the left eye of their subject. However, I would like the authors to address one other finding in the figure. Observing the small right pupil in the adducted eye, did the authors consider whether any Tournay phenomenon $^{2}$ was present and whether this would change their etiologic diagnosis? The photograph taken by the patient clearly shows that she is holding her eyes in a leftward direction, which might induce the anisocoria.

Author Response: Aki Kawasaki, Lausanne, Switzerland: Tournay phenomenon is a gaze-evoked anisocoria and is one cause of episodic mydriasis. While the figure happens to show the patient's eyes in lateral gaze, the episodes of pupillary dilation do occur spontaneously when the eyes are in the primary position (i.e., when the patient views her eyes directly in the mirror). Also, Tournay phenomenon does not typically cause such distortion of pupillary shape. For these 2 reasons, we believe the patient's episodes of spontaneous, non-gaze-evoked mydriasis with distortion is best described as tadpole pupil phenomenon.

(C) 2013 American Academy of Neurology

1. Kawasaki A, Mayer C. Tadpole pupil. Neurology 2012;79:949.

2. Cox TA, Law FC. The clinical significance of Tournay's pupillary phenomenon. J Clin Neuroophthalmol 1991;11: 186-189.

DISEASE-MODIFYING DRUGS FOR MULTIPLE SCLEROSIS IN PREGNANCY: A SYSTEMATIC REVIEW

James A. Charles, Bayonne, NJ: Based on fair quality Level 3 evidence, Lu et al. ${ }^{1}$ note that glatiramer
WriteClick: Editor's Choice

acetate (GA) exposure was not associated with lower mean birthweight, lower mean gestational age, preterm birth (37 weeks), congenital anomaly, or spontaneous abortion. However, GA was given an indeterminate recommendation because further research is needed. The results are not compelling: 3 of the 4 existing human studies of GA were small case series.

Infertile couples with lack of pregnancy after 1 year of unprotected regular intercourse represent about $10 \%-15 \%$ of all couples. Lack of pregnancy within 2 years by regular coital exposure represents 5\%-6\% of infertile couples. ${ }^{2}$ GA is a Category B US Food and Drug Administration (FDA) drug because animal reproduction studies have failed to demonstrate a risk to the fetus and there are no adequate and well-controlled studies in pregnant women. ${ }^{3}$

There would be many women with multiple sclerosis (MS) left unprotected without disease-modifying therapy if these agents are discontinued prior to conception attempt. It may be appropriate to recommend and continue GA from conception attempt through pregnancy.

\section{Author Response: Helen Tremlett, Ellen Lu, Colleen} Guimond, A. Dessa Sadovnick, Vancouver, Canada: We thank Dr. Charles for his comments. The few studies that examined in utero GA exposure included relatively low numbers of pregnancies in women with MS ( $\mathrm{n}=12-31)$. These studies lacked sufficient power to draw any firm conclusions. Extreme caution should be applied when extrapolating findings from animal studies to humans. ${ }^{4}$ Interestingly, the FDA is replacing its pregnancy risk categories mentioned in our review due to their limited ability to accurately and consistently convey risk and benefit. ${ }^{5}$ We agree that such changes are important. The risks and benefits of GA use on fetus and mother are unclear, especially when the relapse rate likely decreases naturally during pregnancy ${ }^{6}$ and long-term benefits on disease progression have been questioned. ${ }^{7}$ There is also no evidence that couples with one member having MS are at a greater risk for infertility compared to nonMS couples. Given that on average $90 \%$ of couples become pregnant within 12 months and $68 \%$ within 3 months, ${ }^{8}$ most women with MS will likely be off disease-modifying drugs for only a brief duration. Despite best available evidence, our systematic review is only a suggested guideline. Each case should be 
assessed individually; the ultimate decision regarding GA use must be made jointly by the couple and the physician.

(C) 2013 American Academy of Neurology

1. Lu E, Wang BW, Guimond C, Synnes A, Sadovnick D, Tremlett $\mathrm{H}$. Disease-modifying drugs for multiple sclerosis in pregnancy: a systematic review. Neurology 2012;79: 1130-1135.

2. Forti G, Krausz C. Evaluation and treatment of the infertile couple. J Clin Endocrinol Metab 1998;83:4177-4188.

3. US Department of Health and Human Services. FDA: US Department of Health and Human Services Pregnancy Categories. Available at: http://chemm.nlm.nih.gov/pregnancycategories. htm. Accessed October 2, 2012.
4. Daston GP. Laboratory models and their role in assessing teratogenesis. Am J Med Genet C Semin Med Genet 2011; 157:183-187.

5. Law R, Bozzo P, Koren G, Einarson A. FDA pregnancy risk categories and the CPS: do they help or are they a hindrance? Can Fam Physician 2010;56:239-241.

6. Confavreux C, Hutchinson M, Hours MM, CortinovisTourniaire P, Moreau T. Rate of pregnancy-related relapse in multiple sclerosis: Pregnancy in Multiple Sclerosis Group. N Engl J Med 1998;339:285-291.

7. Munari L, Lovati R, Boiko A. Therapy with glatiramer acetate for multiple sclerosis. Cochrane Database Syst Rev 2004;5:CD004678.

8. Gnoth C, Godehardt D, Godehardt E, Frank-Herrmann P, Freundl G. Time to pregnancy: results of the German prospective study and impact on the management of infertility. Hum Reprod 2003;18:1959-1966.

\section{CORRECTIONS}

Intrathecal EBV antibodies are part of the polyspecific immune response in multiple sclerosis

In the article "Intrathecal EBV antibodies are part of the polyspecific immune response in multiple sclerosis" by C. Otto et al. (Neurology ${ }^{\circledR}$ 2011;76:1316-1321), there is an error in the data. Three "patients with cerebral PTLD" should have been designated as "patients with presence of EBV in the CNS." This error does not change the conclusions of the paper. The authors regret the error.

\section{Provocation of migraine with aura using natural trigger factors}

In the article "Provocation of migraine with aura using natural trigger factors" by A. Hougaard et al. (Neurology ${ }^{\circledR} 2013 ; 80$ : 428-431), there is an error in the author list. The second author's complete name should read Faisal Mohammad Amin. The authors regret the error. 


\section{Neurology}

Disease-modifying drugs for multiple sclerosis in pregnancy: A systematic review James A. Charles, Helen Tremlett, Ellen Lu, et al. Neurology 2013;80;1068-1069

DOI 10.1212/01.wnl.0000428359.07207.f6

This information is current as of March 11, 2013

Updated Information \& Services

References

Permissions \& Licensing

Reprints including high resolution figures, can be found at: http://n.neurology.org/content/80/11/1068.2.full

This article cites 7 articles, 2 of which you can access for free at: http://n.neurology.org/content/80/11/1068.2.full\#ref-list-1

Information about reproducing this article in parts (figures,tables) or in its entirety can be found online at:

http://www.neurology.org/about/about_the_journal\#permissions

Information about ordering reprints can be found online:

http://n.neurology.org/subscribers/advertise

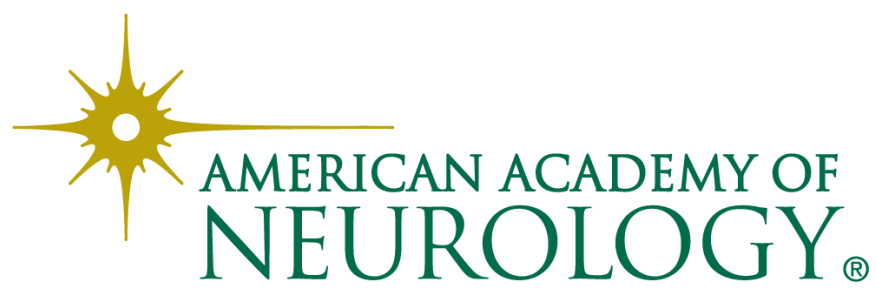

